\title{
Civil Religion on a Confucian Basis
}

\section{Civil Religion for a Future China}

The fact that Tang's ideas about a Chinese democracy are anticipatory in character becomes particularly evident in his writings concerning the role of Confucian religiosity within a future democracy. In this context, Tang developed the notion of a Confucian-based civil religion. ${ }^{1}$ This civil religion is to serve as a basis for civic virtues, including the virtue of religious tolerance. In order to outline the historical form, the dogmatic contents, as well as the social and political functions and effects of a future civil religion, Tang made reference to his concept of a Confucian civil theology and, above all, to the civiltheological limit-concepts of the sage and (moral) intuition.

Tang's concept of a Confucian-based civil religion is embedded in historical claims which entail temporal and normative implications. These implications can be readily clarified by briefly considering comparable constellations in Western concepts of civil religion. First of all, in relating Tang's approach to civil religion to research on civil religion in the United States, we may note that in the American case, there is a predominantly descriptive-analytical framework based on the assumption that civil religion is actually extant in American society. Civil religion in the United States is consequently treated as a phenomenon which can be observed in historical time and space. In

1 With respect to terminology, it should be noted that Tang did not use a direct verbal equivalent to "civil religion" in Chinese. Translations of terms like "civil religion," "civic religion," and the French "religion civile" were not yet current in the Chinese-language discourse on religion of the 1950 and 60 . Tang referred to the idea of a civil religion with various Chinese terms, and most of these terms not only cover the concept of civil religion, but also other meanings. Among these terms, the following are the most common: "religiosity" (zongjiaoxing), "religious spirit" (zongjiao jingshen), and "complete religion" (wanman de zongjiao 完滿 的宗教); see Tang, Renwen jingshen zhi chongjian, p. 594. The term "renewed Confucianism" (xin ruxue 新儒學) also deserves special attention in this context. In one of the few instances where Tang applied it, he referred to the role of religions in China and reminded his readers that Buddhism had an impact on neo-Confucianism in the Song and Ming Dynasties. In analogy to this Buddhist-inspired formation of neo-Confucianism, he concluded that religions might "initiate" the formation of a "renewed Confucianism" and a future "renaissance" of "the religious spirit which was originally present in Chinese culture." See Tang, Zhongguo renwen jingshen zhifazhan, p. 34 . 
contrast, such an assumption is rejected, for example, in the case of post-war Germany. Researchers from the disciplines of sociology, political science, philosophy, and intellectual history have not reached a consensus whether a civil religion - or at least some related phenomena - actually evolved in Germany after the war. Yet another approach can be found in Jean-Jacques Rousseau's classical depiction of a civil religion or "religion civile." Rousseau developed his concept of civil religion in section eight of the final chapter of his Du contrat social with the intention of anticipating a civil religion for a future community. In so doing, Rousseau interpreted extant Christian denominations with the goal of reducing their dogmatic contents to the point where they should become generally acceptable as a civil religion across different denominations.

Civil religion as conceptualized by Tang may, mutatis mutandis, be labeled Rousseauian insofar as it functions as an anticipation of the future: Neither the Chinese democracy nor the civil religion which Tang foresaw as instrumental for the implementation of civic virtues such as religious tolerance, were yet in existence. But whereas Rousseau devised the idea of a civil religion to bolster his theory of social contract, Tang conceived of a civil religion with the goal of redefining the role of Confucian religiosity in modern society. This entailed an attempt to counter ideas of a Confucian theocracy (Kongjiao 孔教), a dogmatic Confucianism (as in the authoritarianism of the GMD), and a political religion (Marxism-Leninism, Maoism).

In order to achieve the status of a civil religion in a future Chinese democracy, the religious convictions inherent in Confucianism would have to be conducive to the unity and stability of a democratic community in China. This involves, first of all, the idea of the emancipation from the shackles of politicalreligious dogmatism and authoritarian claims made in the name of ostensibly traditional (Confucian) values and virtues. At the same time, the civil-religious convictions were to compensate for the loss of traditional worldviews in modern society. Here, Tang's concept of civil religion is in accord with what Robert $\mathrm{N}$. Bellah analyzed as a fundamental idea of American republicanism, namely, that a republic needs an encompassing system of values symbolized in a civil religion. The democratic republic aims at fostering an ethical commitment from its citizens, and the civil religion serves as a symbolic representation of a higher order that gives meaning to republican virtues and values. ${ }^{2}$

But Tang and Rousseau, and possibly also Bellah, differed in their ideas about engendering the citizen's willingness to act upon civic virtues. Rousseau, like the mainstream of Enlightenment philosophy, believed that the citizens needed the assurance of a reward for virtuous deeds that was to be obtained, if

2 Bellah, "Religion and Legitimation in the American Republic," p. 197. 
not in this world, then in the afterlife. ${ }^{3}$ In contrast, the Confucian citizens are left on their own, without any reassurance of a reward in an afterlife or in the present. They are expected to accept the burden of virtuous behavior based on the demand to engage in self-cultivation, even if the prospects of success, i.e. becoming a sage, are dim. Confucian religiosity is, after all, in essence a religiosity of individual inwardness without a notion of divine grace.

Based on his distinction between world religions and the religiosity (or the "religious spirit") of a renewed Confucianism, Tang assumed that Confucian religiosity is better suited than the world religions to foster civic virtues in general, and religious tolerance in particular. More specifically, he expected that Confucian religiosity can provide a foundation for other religions to attain a position of mutual "recognition" in China's (future) "humanistic world" (renwen shijie 人文世界). ${ }^{4}$ Tang's notion of religiosity is here in line with European concepts of religiosity, which evolved from the late 18th century. These concepts essentially served to anchor religion in reason while, at the same time, highlighting moral duties as an integral element of religion. ${ }^{5}$ In this regard, Enlightenment notions of religiosity accord with ideas of a civil religion, including the concept of a Confucian-based civil religion in China.

However, some qualifications need to be made here. For one, a typical feature of Western notions of civil religion is absent from Tang's reflection on the social and political role of Confucian religiosity within a democracy: Tang did not attempt to reduce the dogmatic contents of Confucianism, Daoism, and Buddhism, whereas it was common practice among European thinkers to conceive of a minimizing of Christian dogmas. This reductive move was meant to defuse tensions between different Christian denominations, which were singled out as potential triggers of religious and civil war in European history. In contrast, Tang found no traces of a malignant dogmatism in Confucianism. The dogmatic content of "[religious] Confucianism" (rujiao 儒教), as he pointed out, merely enticed with the idea that

3 Forschner, "Rousseau über religion civile," pp. 24-25, 34.

4 Tang, Zhongguo renwen jingshen zhi fazhan, p. 389.

5 Ritter et al., Historisches Wörterbuch der Philosophie, pp. 653-654. Both deism and notions of a religion of reason ("Vernunftreligion") evolved in the intellectual context of the European Enlightenment, namely philosophies of natural law and natural religion dating back to the 17th century. They are consistent with Tang's idea of religiosity insofar as they, too, do not contain ideas of cults, revelation, miracles, or anthropomorphic notions of God: ibid., p. 657; see also Kleger, "Einleitung: Bürgerliche Religion, Religion des Bürgers, politische Religion, Zivilreligion, Staatsreligion, Kulturreligion," pp. 11-12. 
... human beings only need to examine themselves and be sincere ... [so that even] amid the whole turbid and sinful spirit, all of them will be able to perceive this original nature of the highest good, this existence of innate knowing. ${ }^{6}$

Neither did Tang find traces of dogmatism in Daoism and Buddhism. He apparently adopted the traditional cliché of a peaceful integration of the socalled Three Teachings (Confucianism, Buddhism, and Daoism) as a master narrative of China's religious history, and concluded that there was no historical evidence for genuinely religious warfare in China comparable in scale and intensity to the religious wars in Europe. ${ }^{7}$ Moreover, Tang assumed that the three Confucian forms of ritual sacrifice (see below) did not evoke "feelings of religious insistence and urgency" that were as strong as those in world religions which were ecclesiastically organized, relied on revealed sacred scriptures and rigid doctrines, and upheld a fixed monotheistic or polytheistic belief. ${ }^{8}$ Tang's portrayal of Confucian religiosity is, by the way, in some accordance with the image of Chinese "religion" or "theology" held by Sinophile philosophers of the European Enlightenment, such as Voltaire, Leibniz, Wolff and Hume. Still, when interpreting Tang's approach to Confucian religiosity in terms of a civil religion, it is necessary to take into account a shift in perspective: Tang's agenda was to demonstrate that Confucianism actually had a religious dimension of its own, in spite of the fact that there were rampant Western misconceptions of it which denied it profound religious significance. This intention clearly differs from Western agendas of civil religion. For Tang, reinterpreting Confucian religiosity as a civil religion was not a matter of reducing religious dogmatism, but of substantiating that the "Confucian spirit" did have religious significance, even though its dogmatic content was rather thin.

As regards the topic of religious tolerance, Tang is more or less in line with Western ideas of civil religion in that he placed great emphasis on tolerance. He deemed Confucian religiosity exceptionally suitable for infusing religious tolerance into society due to its lack of religious dogmatism and hence tried to convince his readers that Confucian religiosity should serve as a spiritual pivot. Consequently, he discussed at length the potential of Confucian religiosity to open up a "spiritual ground" or "meeting place" for all religions in China and the world. Religious conflicts would hence be peacefully solved and religious

6 Tang, Renwen jingshen zhi chongjian, pp. 590-591.

7 See Tang's depiction of the historical development of humanistic thought in China: Tang, Zhongguo renwen jingshen zhifazhan, pp. 12-32.

8 Ibid., p. 376 . 
tolerance and harmony would be implemented in society by upholding "our Confucian position." ${ }^{\prime 9}$ Crucial in this regard is the assumption that religious tolerance can be promoted in communities by emphasizing and fostering commonalities of religious convictions. ${ }^{10}$ As the minimal content of such commonalities, Tang singled out the civil-theological notion of human nature and its potency to attain moral intuition. Religious tolerance would be established on the basis of Confucian religiosity due to the fact that the Confucian belief in human nature may even tolerate, for example, Judeo-Christian notions of original sin or Brahmanic and Buddhist beliefs in karma. Therefore, no "fundamental" antagonism between Confucianism and Christianity, Buddhism and Brahmanism would persist. ${ }^{11}$ Confucian religiosity is hence said to acknowledge that "different religions are different ways of attaining sagehood... that the ultimate destination of all the ways may be the same, but that no one way is itself ultimate."12 On this premise, Tang claimed that:

[A] man with moral sincerity can rise above the frontier of particular knowledge to attain an exalted and intimate realization of the origin of the universe and human life, whether he lives and behaves according to Confucianism, Taoism, or Buddhism, or solely engages himself in reflecting on his personal status amid human communities and history. ${ }^{13}$

But even if one were willing to endorse the conviction that Confucian religiosity is such a source of religious tolerance, a number of questions remain. For one, Tang never elucidated the role of Confucianism vis-à-vis dogmatic or social tensions and conflicts between non-Confucian religions. Nor did he clarify the implications of his accentuation of Confucianism as the religious "meeting place" in terms of constitutional law. There is no doubt that Tang situated his discussion of religious tolerance within the context of a liberal constitution that guarantees religious freedom. But since he did not treat this subject in depth, we can only assume that he was convinced that the burden of legal enforcement of religious freedom and tolerance in society had to be

9 Ibid., pp. 389-390; see also Tang, "The reconstruction of Confucianism and the Modernization of Asia," pp. 366-367; and Tang, Renwen jingshen zhi chongjian, pp. 591-593.

$10 \quad$ Tang, Renwen jingshen zhi chongjian, p. 591.

11 Tang, "The Development of Ideas of Spiritual Value in Chinese Philosophy” [1968], p. 8.

12 Tang, "Chinese Attitudes Towards World Religions," p. 330.

13 Tang, "My Option between Philosophy and Religion," p. 425. See also Tang, Zhongguo renwen zhi jingshen fazhan, p. 369 . 
strictly separated from the task of Confucian religiosity to create a spiritual "meeting place" for religious believers. The latter must not compete with constitutional guarantees of religious freedom and should reject any aspiration of dominating the state and the constitutional process. After all, the agenda of the modern revival of Confucianism was not to be defined by dominating the constitutional order and turning the modern state into a Confucian state. It is against this backdrop that Tang criticized neo-Confucianism from the Song and Ming Dynasties for having established an antagonistic relationship between Confucian teachings and other religions. ${ }^{14}$

The modern form of Confucian religiosity is said to contain neither a sort of catechism, nor a clerical structure that could lead to the establishment of a Confucian state religion. Nonetheless, it has certain ritualistic forms. Tang identified the aforementioned three forms of ritual sacrifice and stressed not only their local particularities, but also the highly individualized character of these rituals: Individuals worship their own ancestors, saints, and worthies in these core rituals of Confucianism and, what is more, these rituals are highly diverse in form and content depending on the professions of the worshippers and the localities where they are performed. According to Tang, Confucian rituals therefore cannot be amalgamated into a universal church, even though there are indeed some rituals of a unitary character, such as those performed to honor Confucius, the Yellow Emperor, or Heaven and Earth. ${ }^{15}$ Although Tang conceded here that Confucian religiosity in fact contained some unitary elements of ritual practice, he still claimed that these rituals were never integrated into a Confucian clerical and doctrinal structure comparable to the organizational patterns of (world) "religions." ${ }^{16}$ Tang consequently predicted that the project of strengthening Confucian religiosity in modern society cannot be accomplished by political, clerical, academic, or economic organizations. Such an effort should be undertaken by precursors who do not build an "[organizational] form," but maintain the mutual relations of "teachers and friends" engaged in social, cultural, political and academic practice, and strive for a moral conduct of life. The renewed Confucian religiosity would then slowly diffuse throughout society in a non-hierarchical manner. This outlook must have been particularly attractive for Confucian intellectuals who were driven by a strong sense of mission to stop the decline of the (religious)

\footnotetext{
14 Tang, Zhongguo renwen jingshen zhi fazhan, p. 369.

15 Ibid., pp. 376, 378, 381.

16 Ibid., p. 376.
} 
"Confucian spirit,"17 while struggling with the difficulties of establishing a solid organizational framework in exile after 1949.

With respect to world religions, Tang noted with "deepest regret" that the followers of Christianity, which he depicted as the strongest religious force in the contemporary world, but also Buddhists and Muslims, could not yet accept "the value of divergent religions." ${ }^{18}$ It is the prevention of future religious conflicts which was on Tang's agenda here. ${ }^{19}$ From this perspective, he interpreted the religious history and dogmatic developments of Christianity in close relation to his Confucian matrix of religious tolerance. By focusing on Christianity, he portrayed the West as a zone of latent religious warfare dominated by hostile Christian denominations and suggested that future religious tolerance would evolve on a global scale on the intellectual foundation of Confucianism. But still, he remarked, it would be crucial to further develop "harmonizing notions" that already exist within Christianity. ${ }^{20}$

There are three problematic consequences of this approach. First, Tang disregarded the traditions of religious tolerance, and civil religion for that matter, which have evolved in the West. The irony here is that Tang himself reflected on historical traces of religious tolerance within Christianity in a manner that is indeed common in Western notions of civil religion, namely, by applying the strategy of reducing the dogmatic contents of Christianity to a minimum in order to dissolve the danger of conflicts sparked by confessional differences. Second, Tang's interpretation of Christianity as well as other world religions is highly idiosyncratic and also simplistic, if not reductionist, in terms of religious history and theology. This pertains to the very selective way of viewing certain dogmatic and institutional aspects of Christianity, among them the idea of exclusive salvation as offered by divine grace, the idea of original sin, and the absence of a belief in the mundane perfectibility of man, as well as the clerical institutions and organizations. ${ }^{21}$ As for other "world religions" like Islam, Judaism, or Buddhism, but also Daoism, they are only incidentally mentioned in this context. Third, Tang tended to interpret the religious commitment of devotees of world religions from a highly rationalistic perspective. Their religious commitment and fervor is thus seen as if it had resulted from a

\footnotetext{
17 Ibid., pp. 390-391.

18 Tang, Renwen jingshen zhi chongjian, p. 564. Judaism is marginalized in Tang's discussion of world religions.

19 Ibid., p. 593; Tang, Zhongguo renwen jingshen zhifazhan, p. 377.

$20 \quad$ Tang, Renwen jingshen zhi chongjian, p. 564.

21 Tang, Zhongguo renwen jingshen zhi fazhan, p. 377; Tang, Renwen jingshen zhi chongjian, pp. 592-594.
} 
conscious choice or even a rational decision taken by the individual believers. Tellingly, Tang forwent a clear conceptual distinction between religious devotion and the conscious choice of certain (religious) values by individuals.

These problematic issues in Tang's reflection on religion are, to a certain extent, due to the fact that he did not conceive of civil religion as a historical reality in China. As a projection of a future social reality, his conceptualization of a Chinese civil religion tended to produce reductionist depictions of religious history and schematic representations of dogmatic aspects of Confucian religiosity and world religions. There is, one may conclude, a high likelihood of failure in attempts to implement a civil religion as an intervention into social reality. It seems that Tang was aware of the precarious nature of his vision to inscribe Confucian religiosity into the democratic life of (future) Chinese society. He preferred instead to imagine its formation as a gradual development initiated, but not engineered, by a minority of individuals. He expected, in other words, that the development of civil religion in China should be perceived, in hindsight, as the outgrowth of a historical evolution, not as the result of a target-orientated project.

\section{Political Ideals and Reality}

There is yet another reason why Tang did not devise a plan for the implementation of a Confucian-based civil religion in modern China. Such an effort would, after all, easily deteriorate into the ideological ambition to impose a higher religious truth on political reality. This would run counter to the fundamental assumption of Tang's Confucian civil theology that (moral) truth-i.e. the moral intuition of the "principles of Heaven"-is only indirectly related to political reality, namely, as a positive limit-concept. Notions of an immediate presence of absolute truth in political reality, as exemplified for example by the imperial figure of the Son of Heaven, have been abandoned by modern Confucianism.

One crucial implication of the Tang's civil theology is that any implementation of absolute truth claims in political reality inevitably subdue individuals' subjectivity and thus deprive them of the opportunity to actualize their (moral) nature in the course of their social and political life. As a consequence, Tang did not conceptualize political order and institutions as representations of an ultimate truth. He understood the modern world to be fatally fractured and inevitably devoid of a substantial harmony between the realm of Heaven, the human being, and political reality. Modern subjects should therefore brace themselves for the somber fact that political reality never totally accords with 
the exigencies of individual self-fulfillment. Tang's political thought indeed insists that modern society cannot be accommodated by a pre-modern, ecumenical speculation about the representation of a "Heavenly mandate," because the substantial unity of political form and Heavenly order is irreversibly broken. What is left, is a sharp conceptual distinction between the individual's "inner sagehood" and the "renewed outer king" (i.e. the renewed political form), and their communion is irrevocably called into question. The lacuna that now separates the two requires an effort of reflection in order to retrieve their inter-relation. This effort is undertaken by modern Confucianism via such categories as "ideals" (lixiang), "values" (jiazhi), and "spirit" (jingshen), and hence in reference to newly coined terms which were unheard of in preimperial and imperial China.

The orientation towards political ideals has consequences for the anticipation of political reality in modern Confucianism. For one, the category of ideals indicates that political reality will never be fully consistent with it. By introducing "ideals," Tang's speculation precludes expectations of an instantaneous implementation of a perfect political community. Tellingly, Tang did not issue political prescriptions for the realization of allegedly superior Confucian ethics. His approach here might cause uneasiness among apologists of Confucianism who muse over the superiority of a Confucian democracy, or meritocracy, even before democracy is established in China. As a matter of fact, Tang cautioned against the idea of a meritocracy in which worthy and able persons are recommended for and promoted to office, deeming it a “distant view" (yuanjing 遠景) that transgresses the present world and cannot be realized in a “leap" (yue 越). ${ }^{22}$ It would necessitate a corresponding attitude among citizens, which would, at best, gradually emerge from the core humanistic realm, and only "perhaps" do so under the influence of the Confucian intellectual tradition. ${ }^{23}$ In the same vein, Tang called attention to the fact that abstract, universal ideals-including the ideal democracy - may at most initiate the unification of individuals, but they cannot produce a complete reality out of themselves. ${ }^{24}$ In accordance, approaches to realizing political ideals should take shape on the basis of a gradual transformation of cultural and ethical values. For Tang, safeguarding such an evolution of values and attitudes was the ultimate purpose of politics. ${ }^{25}$

Given Tang's cautious reflection about the relation between political ideals and political reality, it seems that contemporary critics who denounce his

\footnotetext{
22 Tang, Zhonghua renwen yu dangjin shijie, Vol. 2, p. 140.

23 Ibid., p. 138.

24 Ibid., p. 105.

25 Ibid., p. 141.
} 
modern Confucianism as too lofty or too "philosophical" miss a crucial point. Tang did not intend to submit political reality to a dictate of ideals under the pretense of effectuating an immediate political impact. This is not to say that he rejected the idea of making political ideals a yardstick for reality, but he remained careful to clarify and restrict their function. Here, a quasi-Platonic, cognitivist paradigm becomes obvious: Tang clearly conceptualized the foundation of political order as resting on the insight of its members into the guiding principle of the order itself. ${ }^{26}$ The Confucian political order thus requires the awareness of its members that it is based on a specific notion of human nature, which includes the ideal of individual moral self-fulfillment and the ideal of an authentic conduct of life. What is more, the political actors should at all times be aware that politics as such only has an intermediate function in relation to the higher goal of realizing humanistic values.

Political ideals like the ecumenical state embodying ethical life may, according to Tang, only pertain to a distant future. Nonetheless, they are fully situated within the horizon of human history. These ideals thus have a different ontological status than the limit-concepts of the sage or a community of sages. Such a community cannot be realized within history and, indeed, it has no historical dimensions, because the sagely members are identified by the very fact that they dwell in the ahistorical realm of absolute, unchangeable truth. If a community of sages were possible, its members would behave in total unanimity and thus constitute an apolitical community. It is significant that Tang does not consider this vision to be an ideal and refrains from devaluating political reality altogether by contrasting it to a community of sages. Clearly, Tang's Confucian civil theology makes a crucial distinction between limit-concepts and ideals. It is under the label of "ideals" that Tang takes up the task of historicizing and temporalizing limit-concepts. ${ }^{27}$ The figure of the "sage" is hence historicized as the "ideal politician," and the sagely community of intuition is temporalized as the ecumenical state within an ideal humanistic world. But in so doing, Tang did not advocate a complete rejection of political reality. He remained immune to the ideological appeal of claims aimed at a total transformation or a re-founding of political society altogether. His modern Confucianism therefore establishes its critical distance from a political reality which will never be perfect, but is permanently in need of reflection and supportive action that advances it toward an ideal community.

26 On the cognitivist tendency in Plato and in German political thought of the 19th century, see Vollrath, Grundlegung einer philosophischen Theorie des Politischen, p. 57.

27 Tang's notion of ideal clearly differs from Kant's understanding of an ideal; see above Chap. 5 . 